\title{
Cyanobacterial diversity for an anthropogenic impact assessment in the Sør Rondane Mountains area, Antarctica
}

\author{
RAFAEL FERNÁNDEZ-CARAZO' ${ }^{1}$, ZORIGTO NAMSARAEV $^{1,2}$, MARIE-JOSE MANO ${ }^{1}$, DAMIEN ERTZ ${ }^{3}$ and \\ ANNICK WILMOTTE ${ }^{1}$ \\ ${ }^{I}$ Centre for Protein Engineering, Institute of Chemistry B6, University of Liège, 4000 Liège, Belgium \\ ${ }^{2}$ Winogradsky Institute of Microbiology, Russian Academy of Sciences, 117312 Moscow, Russia \\ ${ }^{3}$ Départment Bryophyta-Thallophyta, National Botanical Garden of Belgium, Domain of Bouchout, 1860 Meise, Belgium \\ rafafercaraz@gmail.com
}

\begin{abstract}
The recently inaugurated Belgian Princess Elisabeth Station has been built in the Sør Rondane Mountains (Dronning Maud Land). The construction site is situated close to the Utsteinen Nunatak (71 $57^{\prime} \mathrm{S}$, $23^{\circ} 20^{\prime} \mathrm{E}$ ), on a granite ridge. Prior to the survey and construction activities, the site had been subject to limited or no direct human impacts. Therefore, a biological inventory has been started for future evaluations of human impacts in the area. This study presents the cyanobacterial diversity of ten samples from the Utsteinen ridge, the Utsteinen Nunatak in the vicinity of the station's site and the more distant Ketelersbreen Dry Valley. All samples were taken before the station was built and were studied by light microscopy and Denaturing Gradient Gel Electrophoresis. Two strains were also isolated. Two different phenol-based extraction methods, with and without detergent-based steps, were tested to improve the quality of molecular detection from these environmental samples. We observed high cyanobacterial diversity (ten morphotypes and 13 operational taxonomic units) in comparison to other Antarctic terrestrial locations and a widespread distribution pattern within the Sør Rondane Mountains area. This might reflect the habitat similarities and/or the easy local dispersal capabilities of microorganisms within the region. The high diversity and proportion of potential endemic (46\%) operational taxonomic units, of which $23 \%$ were newly described, suggest that this area could have acted as a biological refuge during past glaciations.
\end{abstract}

Received 16 November 2010, accepted 12 May 2011, first published online 19 December 2011

Key words: Antarctic, biodiversity, Dronning Maud Land, Princess Elisabeth Station, Utsteinen Nunatak, 16S rRNA

\section{Introduction}

The Antarctic continent has remained isolated from the rest of the world since its separation from Gondwana between 100 and 60 million years ago (Ma) (Vincent 2000) and the formation of the Antarctic Circumpolar Current (31-17 Ma) (Lawver \& Gahagan 2003). As Antarctica became isolated from warmer waters and greenhouse gases declined in the atmosphere (Tripati et al. 2005), the continent cooled down and glaciers began to form. Many Antarctic habitats have therefore been created since the formation of the ice sheet (e.g. cryoconites) or have remained intact and isolated from other continents for hundreds to millions of years before present. Nunataks, exposed above the ice sheet, have in some cases remained ice-free for very long periods. They can host living organisms or dormant spores that have the potential to spread under certain conditions and colonize nearby habitats (Gordon et al. 2000), or preserve persistent ancient taxa (Convey et al. 2008). The evidence that some areas in central Dronning Maud Land between 800 and $1380 \mathrm{~m}$ a.s.l. have been ice-free since at least $39.4 \mathrm{ka}$ вр (Wand \& Hermichen 2005) and the persistence of the continental Antarctic mite genus Maudheimia since the Last Glacial Maximum in Dronning Maud Land (Marshall \& Coetzee 2000), could support the idea that the Utsteinen Nunatak has acted as a refuge during glaciations.

Although it is well known that chemical contamination can persist for a long time, little is known about the microbiological impact of anthropogenic activities within Antarctica, other than microbial sewage contamination (Tin et al. 2009 and references therein). There is a rising flux of humans visiting Antarctica, with an increasing number of scientific stations being built (20 permanent stations at present) and about 40000 tourists in 2008-09. Meanwhile, in an attempt to control this "new colonization", the Madrid Protocol on Environmental Protection to the Antarctic Treaty was signed in 1998 to commit signatories to the comprehensive protection of the Antarctic environment, and to designate Antarctica as a natural reserve, devoted to peace and science (http://www.ats.aq/index_f.htm). Recently, the issue of the possible colonization of Antarctic locations by non-native species has been raised (Frenot et al. 2005) and is a priority concern for the Committee for Environmental Protection (http://www.ats.aq/e/cep.htm).

A biological baseline survey of the Utsteinen site was started during the BELARE 2004-07 expeditions. Vertebrate and invertebrate fauna as well as lichens and mosses were described in the Comprehensive Environmental Evaluation

\section{CAMBRIDGE JDURNALS}




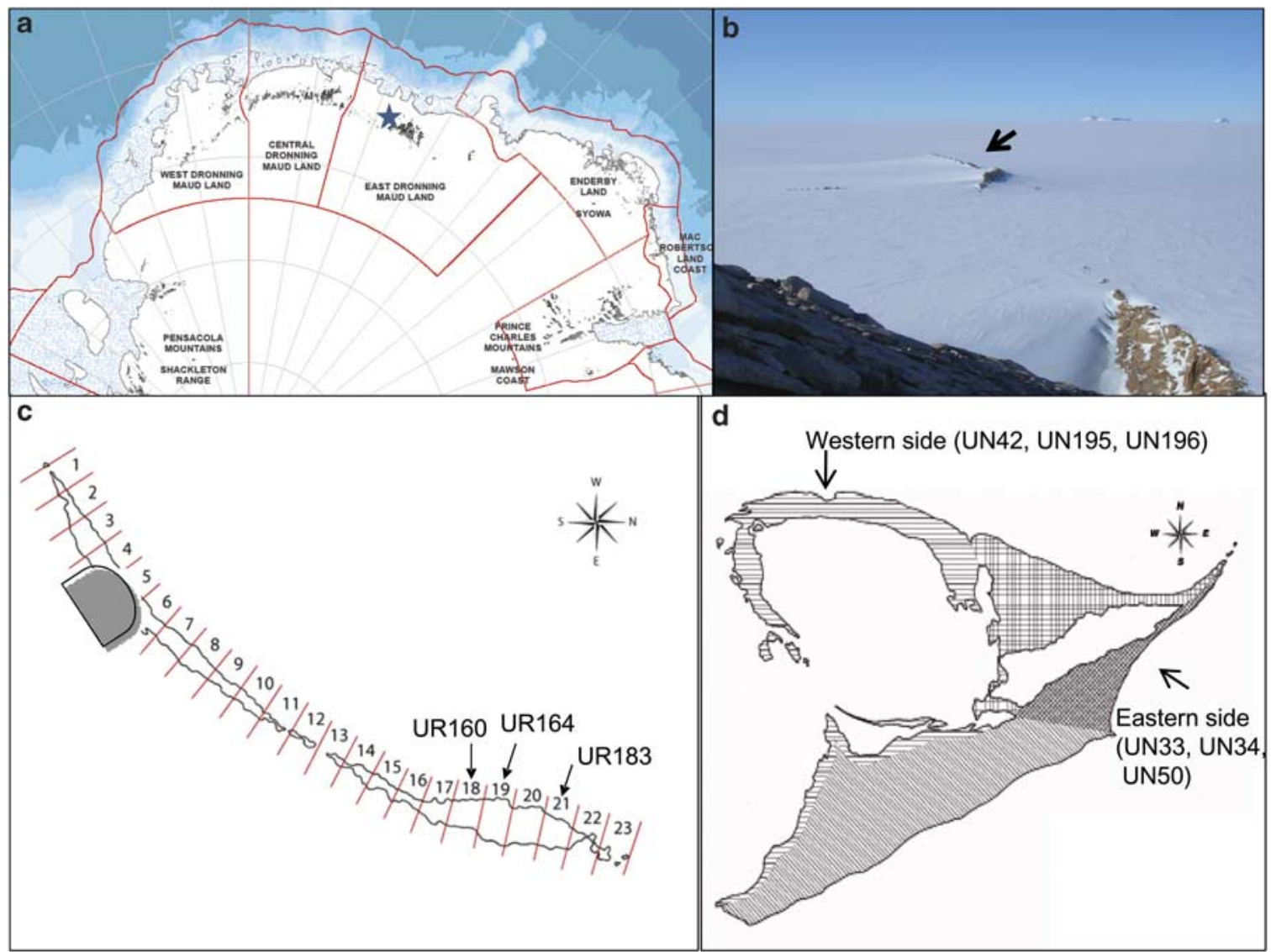

Fig. 1. a. Map of Dronning Maud Land. The star indicates the position of the Utsteinen Nunatak and the ridge. b. View of the Utsteinen ridge (indicated by an arrow) from the Utsteinen Nunatak, looking to the north. c. Sketch map of the Utsteinen ridge. Sampled sections and their corresponding code numbers are indicated by arrows. The Princess Elizabeth station occupies sections 4-6. d. Sketch map of the Utsteinen Nunatak. The western and eastern sides, where samples (in brackets) were collected, are indicated by arrows.

(BelSPO 2007) of the station. Environmental samples were taken for future research on the biodiversity of microorganisms such as cyanobacteria. This survey will allow the accurate monitoring of possible future human impacts of the station on the biodiversity.

We present here a baseline study of the cyanobacterial diversity in the Sør Rondane Mountains area before the installation of the Princess Elisabeth Station. Ten samples were studied by a polyphasic approach, using microscopy and molecular methods, to determine the biodiversity of cyanobacteria in this area. Additionally, two DNA extraction methods have been tested to try to improve the detection limits by the molecular approach. Indeed, the problem of the non detection of genotypes observed by microscopy in environmental samples has been recognized in earlier papers based on a polyphasic approach. For example, Taton et al. (2003) showed that no sequences from Nodularia and Hydrocoryne, were detected by molecular methods although they were observed by microscopy of the environmental samples. Similarly, in Taton et al. (2006a) some morphotypes (e.g. Calothrix, Arthronema and Schizothrix) were only detected by microscopic analysis.

The results of this work will help, in conjunction with other studies on bacteria, algae, lichens and mosses, to compile an extensive inventory of the biodiversity before the construction and activity of the new research station have started. This baseline data, obtained in the frame of the ANTAR-IMPACT expertise pole (BelSPO SD/BA/853, www.antar-impact.ulg.ac.be), is indispensable in monitoring the ongoing impact of the anthropogenic activities in the area.

\section{Material and methods}

\section{Site description}

The site $\left(71^{\circ} 57^{\prime} \mathrm{S}, 23^{\circ} 21^{\prime} \mathrm{E}\right)$ of the Belgian Antarctic station, is c. $200 \mathrm{~km}$ inland from the Princess Ragnhild Coast, in the western part of the Sør Rondane Mountains, Dronning Maud Land (Fig. 1a). The station is situated c. $1 \mathrm{~km}$ north of the Utsteinen Nunatak on a granite ridge (Fig. 1b). The

\section{CAMBrIDGE JDURALS}


Table I. Samples, external aspect and specific locality of sampling. Section numbers from the ridge are indicated in brackets. The two first characters of each sample's name indicate their origin: $\mathrm{UN}=$ Utsteinen Nunatak, UR $=$ Utsteinen ridge, and $\mathrm{KD}=$ Ketelersbreen dry valley.

\begin{tabular}{|c|c|c|}
\hline Sample & External aspect & Locality \\
\hline UN42 & Gravel in a moraine & $\begin{array}{l}\text { Western side of the Utsteinen Nunatak } \\
\left(71^{\circ} 57^{\prime} 28^{\prime \prime} \mathrm{S}, 23^{\circ} 19^{\prime} 04^{\prime \prime} \mathrm{E}, 1320 \mathrm{~m} \text { a.s.1.) }\right.\end{array}$ \\
\hline UN50 & Gravel and microbial mat & $\begin{array}{l}\text { Eastern side of the Utsteinen Nunatak } \\
\left(71^{\circ} 57^{\prime} 30^{\prime \prime} \mathrm{S}, 23^{\circ} 20^{\prime} 48^{\prime \prime} \mathrm{E}, 1415 \mathrm{~m} \text { a.s.1.) }\right.\end{array}$ \\
\hline KD144 & Gravel with water in a cavity of a big boulder & $\begin{array}{l}\text { Ketelersbreen dry valley } \\
\left(72^{\circ} 06^{\prime} \mathrm{S}, 23^{\circ} 09^{\prime} \mathrm{E}, 1700 \mathrm{~m} \text { a.s.1.) }\right.\end{array}$ \\
\hline UR160 & Black microbial mats & $\begin{array}{l}\text { Utsteinen ridge ( } 18) \\
\left(71^{\circ} 56^{\prime} 47^{\prime \prime} \mathrm{S}, 23^{\circ} 20^{\prime} 47^{\prime \prime E}, 1370 \mathrm{~m} \text { a.s.1.) }\right.\end{array}$ \\
\hline UR164 & Black microbial mats & $\begin{array}{l}\text { Utsteinen ridge (19) } \\
\left(71^{\circ} 56^{\prime} \mathrm{S}, 23^{\circ} 20^{\prime} \mathrm{E}, 1375 \mathrm{~m} \text { a.s.1.) }\right.\end{array}$ \\
\hline UR183 & Black microbial mats and gravel & $\begin{array}{l}\text { Utsteinen ridge ( } 21) \\
\left(71^{\circ} 56^{\prime} 44^{\prime \prime} \mathrm{S}, 23^{\circ} 20^{\prime} 43^{\prime \prime} \mathrm{E}, 1370 \mathrm{~m} \text { a.s.1.) }\right.\end{array}$ \\
\hline
\end{tabular}

Utsteinen ridge is $700 \mathrm{~m}$ long, a few metres wide and $1564 \mathrm{~m}$ a.s.l. It is one of the first rocky outcrops between the coast and the Sør Rondane Mountains. The area between the coast and the Sør Rondane Mountains is entirely covered by the ice sheet. The main wind direction at Utsteinen is from the east, a katabatic wind regime coming from the Jenningsbreen Glacier (BelSPO 2007). Air temperature was monitored by an automatic weather station. The mean annual temperature is $-18^{\circ} \mathrm{C}$, with monthly means of $-8^{\circ} \mathrm{C}$ in December 2005 and $-25^{\circ} \mathrm{C}$ in September 2005 . Daily maxima do not exceed $0^{\circ} \mathrm{C}$ in summer, while the daily minimum reaches $-36^{\circ} \mathrm{C}$ in winter. This is a relatively mild climate for the western part of the Sør Rondane, but in general the yearly variations in climate parameters are consistent with a continental climate regime (Pattyn et al. 2000).

The area has been previously visited by Belgian (1958-67) and by Japanese (1987-91) field expeditions before the site survey expeditions in preparation for the Princess Elisabeth Station (BELARE expeditions 2004-07). Although the Utsteinen area itself is pristine, some depots were found in the Sør Rondane Mountains, left by previous expeditions before the entry into force of the Madrid Protocol period (BelSPO 2007).

\section{Sampling}

The samples were taken in January-February 2007. For research purpose, the ridge was divided into 23 sections of $30 \mathrm{~m}$ long transversely across the ridge. We studied ten samples (Table I), of which three were taken from three sections from the ridge (Fig. $1 \mathrm{~b} \& \mathrm{c}$ ), six from the nearby Utsteinen Nunatak (Fig. 1d) and one from the Ketelersbreen dry valley (c. $20 \mathrm{~km}$ to the south) (Figs S1-S5). Samples consisting of soil, gravel (granite) and microbial mats, were collected using sterile Falcon tubes of $15 \mathrm{ml}$ and $50 \mathrm{ml}$ and sterile Whirlpack bags. Part of the collected material was frozen and was kept frozen during air transport to the Belgian laboratories. Duplicates of each of these samples were immediately fixed with $97 \%$ of ethanol for morphological studies and as a back-up.

\section{Morphological characterization and cultures}

Cyanobacterial communities from frozen environmental samples were morphologically characterized. Frozen subsamples were used to obtain isolated strains. Cultures were first inoculated on BG11 solid medium (Rippka et al. 1981) supplemented with $50 \mathrm{mg} \mathrm{l}^{-1}$ of cycloheximide to avoid eukaryotic contaminants and cultured at $12^{\circ} \mathrm{C}$ and $22^{\circ} \mathrm{C}$. Subsequent cultures were realized in BG11 solid medium at $12^{\circ} \mathrm{C}$. Unialgal cultures were obtained by picking single filaments from the edge of discrete colonies after two to three weeks growth on solid media.

Environmental samples and cultures were observed with a Leica DM LB2 microscope (Leica Microsystems GmbH, Wetzlar, Germany) coupled to a Deltapix Invenio Camera (Deltapix, Maalov, Denmark). Cells were measured using the AxioVision software (Carl Zeiss MicroImaging $\mathrm{GmbH}$, Jena, Germany) and results expressed as average of at least ten cells from several filaments/unicellular morphotypes. The taxonomic work of Komárek \& Anagnostidis (2005) and the online database of cyanobacterial genera (http://www. cyanodb.cz, accessed March 2011) were used as references for the identification at the genus or species level.

\section{CAMBrIDGE JDURNALS}




\section{DNA extraction and purification}

Antarctic samples are valuable, because of the difficulties (e.g. remoteness, weather) of sampling in these latitudes. For three samples, two extraction methods were tested to compare their efficiencies in extracting DNA from a maximum of morphotypes. All manipulations were carried out in sterile conditions, with dedicated material, in a polymerase chain reaction (PCR) product free laboratory. A negative control was carried out for each extraction series, using sterile water in place of the mat sample.

The first extraction method was modified from Taton et al. (2003) (henceforth called the 'Taton-derived' method). A $0.5 \mathrm{~g}$ frozen $\left(-20^{\circ} \mathrm{C}\right)$ mat sample was rinsed two times with $1 \mathrm{ml}$ of PBS $\left(154 \mathrm{mM} \mathrm{NaCl}, 2.7 \mathrm{mM} \mathrm{NaH}{ }_{2} \mathrm{PO}_{4}, 7.6 \mathrm{mM}\right.$ $\left.\mathrm{Na}_{2} \mathrm{HPO}_{4}\right) .0 .25 \mathrm{~g}$ of sterile glass beads $(0.17-0.18 \mathrm{~mm}$ diameter; Braun Biotech, Melsungen, Germany) were added and the sample ground with a micropestle (Eppendorf, Hamburg, Germany) several times in a $2 \mathrm{ml}$ Eppendorf tube. Then, $250 \mu \mathrm{l}$ of SNT solution $(500 \mathrm{mM}$ Tris-HCl pH 8 , $100 \mathrm{mM} \mathrm{NaCl}, 25 \%$ saccharose) supplemented with $130 \mu \mathrm{l}$ of fresh lysozyme $\left(50 \mathrm{mg} \mathrm{ml}^{-1}\right)$ was added. We continued to disrupt the cells with the pestle for $1 \mathrm{~min}$ and added another $250 \mathrm{ml}$ of SNT solution. The suspension was then incubated for one hour at $37^{\circ} \mathrm{C}$ with vortexing every $15 \mathrm{~min}$. After this incubation, $0.5 \mathrm{ml}$ of solution II (TRIS Base $500 \mathrm{mM}$, EDTA $500 \mathrm{mM}$, SDS $1 \%$, phenol $6 \%$ ) was added and the suspension vortexed continuously for $30 \mathrm{~min}$. The suspension was then placed on ice for one hour and shaken by vortex every $10 \mathrm{~min}$. After this incubation, the suspension was centrifuged for $10 \mathrm{~min}$ at $16000 \mathrm{~g}$ (Centrifuge 5424, Eppendorf). $1 \mathrm{ml}$ of the supernatant was mixed with an equal volume of phenol, after which it was centrifuged for $5 \mathrm{~min}$ at $16000 \mathrm{~g}$. The aqueous phase was then transferred into a new tube. In some cases, the high salinity can cause a phase inversion. Then, an equal volume of phenol-chloroform-isoamyl alcohol (25:24:1) was added and re-extracted with equal volume of chloroformisoamyl alcohol (24:1). Then, a standard Na acetate-ethanol precipitation was performed, and the dried pellet was resuspended in $200 \mu \mathrm{l}$ of $\mathrm{TE}^{-4}$ buffer (10 mM Tris-HCL pH 8, $0.1 \mathrm{mM} \mathrm{Na} \mathrm{NaDTA}_{2} \mathrm{pH}$ 8). The extracted environmental DNA was purified with the Wizard DNA clean-up system (Promega, Madison WI). The DNA was eluted by adding $100 \mu l$ of $\mathrm{TE}^{-4}$ buffer.

In the 'Wilson-derived' method, $0.5 \mathrm{~g}$ of frozen mat sample was transferred to a sterile $2 \mathrm{ml}$ Eppendorf tube with $0.25 \mathrm{~g}$ of sterile glass beads and manually ground with a micropestle. The sample was washed three times in hot $\left(80^{\circ} \mathrm{C}\right) \mathrm{TE}$ buffer $\left(50 \mathrm{mM}\right.$ Tris, $40 \mathrm{mM}$ EDTA) and incubated at $80^{\circ} \mathrm{C}$ for $5 \mathrm{~min}$ between washings. $1 \mathrm{ml}$ of 5\% Sarcosyl (SERVA, Heidelberg, Germany) was added, and then the sample was kept at $30^{\circ} \mathrm{C}$ for one hour with vortexing every $15 \mathrm{~min}$. Pellets were frozen at $-20^{\circ} \mathrm{C}$ overnight and then re-suspended in $600 \mu$ of TE buffer by repeated pipetting. $30 \mu \mathrm{l}$ of $10 \%$ SDS (SIGMA, Steinheim, Germany) and $3 \mu \mathrm{l}$ of $20 \mathrm{mg} \mathrm{ml}^{-1}$ proteinase $\mathrm{K}$ (MBI
Fermentas, Vilnius, Lithuania) were added, followed by incubation at $60^{\circ} \mathrm{C}$ for one hour. Then, $100 \mu l$ of $5 \mathrm{M} \mathrm{NaCl}$ and $80 \mu \mathrm{l}$ of cetyltrimethylammonium bromide $(\mathrm{CTAB}) / \mathrm{NaCl}$ (2\% CTAB; $100 \mathrm{mM}$ Tris.Cl, $\mathrm{pH} 8 ; 20 \mathrm{mM}$ EDTA, pH 8; $1,4 \mathrm{M} \mathrm{NaCl}$ ) solution were added, mixed thoroughly and incubated for $60 \mathrm{~min}$ at $65^{\circ} \mathrm{C}$. Equal volume of chloroform/ isoamyl alcohol (24:1) was added, mixed thoroughly and centrifuged for $5 \mathrm{~min}$ at $16000 \mathrm{~g}$. The supernatant was transferred to a new tube and then an equal volume of phenol/chloroform/isoamyl alcohol was added, mixed gently and centrifuged for $5 \mathrm{~min}$. The supernatant was transferred to a new tube and supplemented with 0.6 vol of cold $\left(-20^{\circ} \mathrm{C}\right)$ isopropanol mixed gently and incubated at $-20^{\circ} \mathrm{C}$ overnight in a refrigerator. The pellet was centrifuged at maximum speed for $5 \mathrm{~min}$ and washed with $1 \mathrm{ml}$ of $70 \%$ ethanol. Finally DNA was eluted in $100 \mu \mathrm{l}$ of $\mathrm{TE}^{-4}$ buffer. DNA was purified as above.

All the samples were extracted by the Taton-derived method, while three samples were tested with both methods to allow for a comparison of the extraction efficiency.

\section{DNA amplification and Denaturing Gradient Gel Electrophoresis (DGGE) analysis}

All the samples were analysed by PCR-DGGE. DGGE bands were sequenced using the 16S781R and/or $16 \mathrm{~S} 378 \mathrm{~F}$ primers to obtain sequences of $c .370$ base pairs (bp). All the primers used in this work appear in Taton et al. (2003) with the exception of 16S781R (GACTACWGGGGTATCTAATCCCWTT). DGGE was performed twice for each sample to ensure the reproducibility (Figs S6-S11 \& Table S1). The marker was provided by Sylvie Cousin (University of Ghent, personal communication 2006). The PCR products were obtained after two successive PCR reactions (the second one is a seminested PCR) to amplify a segment of the $16 \mathrm{~S}$ rRNA, except in one DGGE gel with the sample UR164 where a single PCR was also carried out to test the influence of the PCR method in the diversity output (Fig. S11). The negative controls included the controls without DNA for the DNA extraction, the first and second PCR reactions and were treated exactly like the real samples. The two successive PCR reactions yielded $422 \mathrm{bp}$ long fragments with a GC clamp attached at the 3' end of the reverse primer. The first PCR used the primers $16 \mathrm{~S} 378 \mathrm{~F}$ and 23S30R. The second semi-nested PCR reaction was performed with $16 \mathrm{~S} 378 \mathrm{~F}$ and 16781R(GC)(a) and (b), primers designed to target specifically the filamentous (a) and unicellular (b) cyanobacteria, respectively (Boutte et al. 2006). These primers target the V3 and V4 variable regions within the 16S rRNA gene (Nübel et al. 1997). For the first PCR, $0.5-1 \mu l$ of the isolated DNA was used as template. The amplification mixture contained $1 \mathrm{X}$ Super Taq Plus buffer, $1 \mathrm{mg} \mathrm{ml}^{-1}$ BSA (bovine serum albumin), $200 \mu \mathrm{M}$ dNTP mix, $0.5 \mu \mathrm{M}$ of each of the forward and reverse primers and $1 \mathrm{U}_{\mu l^{-1}}$ of SuperTaq Plus (HT Technology, Cambridge, UK) in a final volume of $50 \mu \mathrm{l}$. The amplification was performed using an Icycler (Bio-Rad,

\section{CAMBridge JOURNALS}




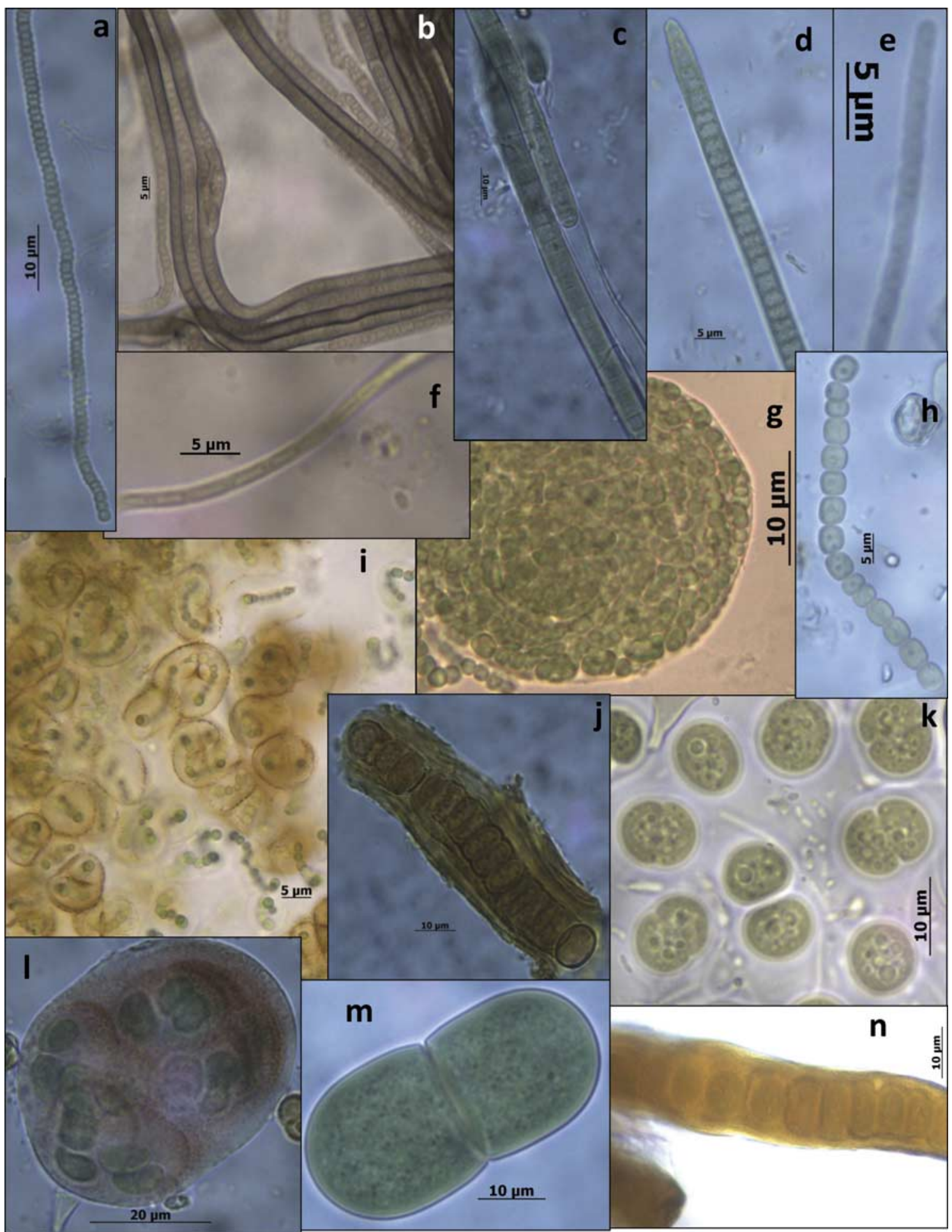

Fig. 2. Diversity of cyanobacterial morphotypes identified in the environmental samples and cultures. a. Phormidium priestleyi, b. strain Phormidium priestleyi ANT-UTS195, c. \& d. Phormidium autumnale, e. Phormidium sp., f. Leptolyngbya Antarctica, g. Nostoc sp., h. \& i. strain Nostoc sp. ANT-UTS183, j. Coleodesmium sp., k. Chroococcus sp., l. Asterocapsa sp., m. Cyanothece aeruginosa, and n. Stigonema sp.

Hercules, USA). The PCR programme included an initial denaturation at $94^{\circ} \mathrm{C}$ for $5 \mathrm{~min}$, followed by $15-27$ cycles with a denaturing step of $45 \mathrm{sec}$ at $94^{\circ} \mathrm{C}$, an annealing step of $1 \mathrm{~min}$ at $54^{\circ} \mathrm{C}$, and an elongation step of $1.5 \mathrm{~min}$ at $68^{\circ} \mathrm{C}$. The final elongation was done during $7 \mathrm{~min}$ at $68^{\circ} \mathrm{C}$. The number of cycles was adjusted to give enough PCR products after the

\section{CAMBRIDGE JDURNALS}


Table II. Morphotypes found by microscopy in the environmental samples.

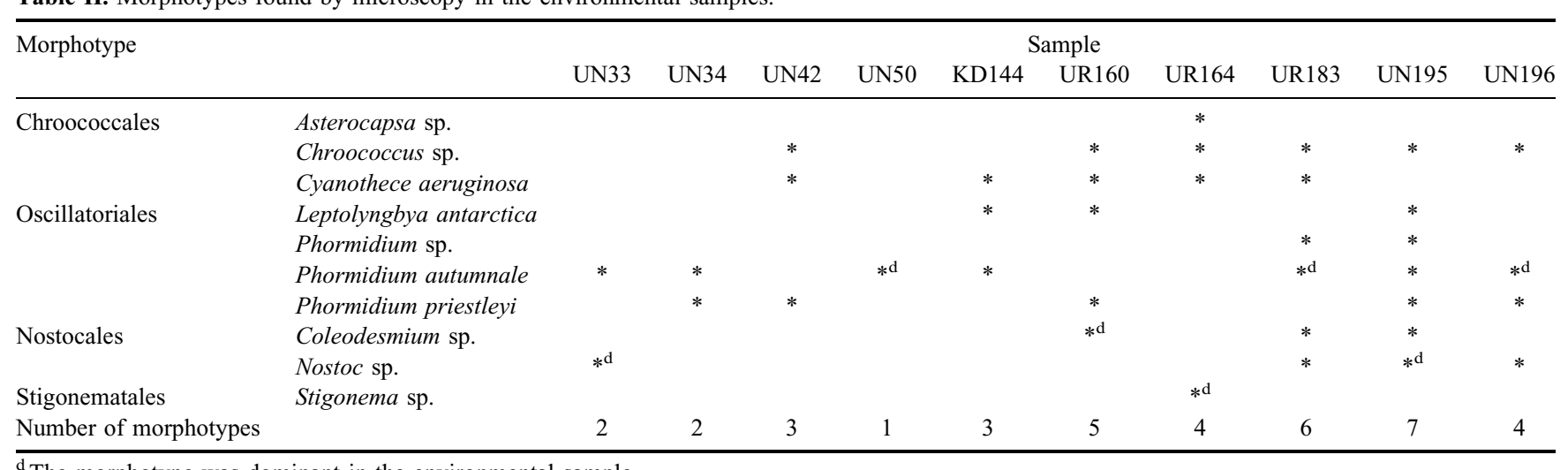

${ }^{\mathrm{d}}$ The morphotype was dominant in the environmental sample.

second PCR without producing unspecific reactions in the controls, and was different for (a) and (b) and for each sample. Indeed, the concentrations of filamentous and unicellular cyanobacteria differed in each case. For the second PCR, $1-4 \mu l$ of the first PCR product was then used as template (same composition as above, except for the primers used). This was performed with a combination of the forward primer $16 \mathrm{~S} 378 \mathrm{~F}$ and the reverse primers $16 \mathrm{~S} 781 \mathrm{R}(\mathrm{GC})(\mathrm{a})$ and (b), separately. The programme included an initial denaturation at $94^{\circ} \mathrm{C}$ for $5 \mathrm{~min}$, followed by $15-27$ cycles with a denaturing step of $1 \mathrm{~min}$ at $94^{\circ} \mathrm{C}$, an annealing step of $1 \mathrm{~min}$ at $60^{\circ} \mathrm{C}$, and an elongation step of $1 \mathrm{~min}$ at $68^{\circ} \mathrm{C}$. A final elongation step of $20 \mathrm{~min}$ at $68^{\circ} \mathrm{C}$ was finally performed. For the direct PCR, the primers $16 \mathrm{~S} 378 \mathrm{~F}-16 \mathrm{~S} 781 \mathrm{R}(\mathrm{GC})(\mathrm{a})$ and $16 \mathrm{~S} 781 \mathrm{R}(\mathrm{GC})(\mathrm{b})$ were used with the same cycling programme as described above.

The PCR products with the GC clamp were analysed by DGGE following the protocol of Boutte et al. (2006) with some modifications. We used a $6.5 \%$ acrylamide gel
(Protogel acrylamide/bis 37.5/1) (w/v) (National Diagnostics, Atlanta, USA) and a denaturing gradient of 40-65\%. Excised DGGE bands were incubated in $\mathrm{TE}^{-4}$ buffer $(10 \mathrm{mM}$ Tris-HCL $\mathrm{pH} 8,0.1 \mathrm{mM} \mathrm{Na}_{2}$ EDTA pH 8 ) for 12 hours at $4^{\circ} \mathrm{C}$ and used as template for PCR re-amplifications (primers 16S378R and 16S781R). DNA purification was performed with the Illustra DNA and band gel purification Kit (GE Healthcare, Diegem, Belgium). When a band class (group of bands from different samples that migrate at the same position) was present in several samples, at least two bands were sequenced. Sequencing was carried out by GIGA (Liège, Belgium, http://www.giga.ulg.ac.be) using an ABI 3730 xls DNA analyser (Applied Biosystems, Foster City, USA).

\section{Analysis of sequence data}

When several bands from the same sample showed the same sequence, we selected the longest one with the best

Table III. Presence of operational taxonomic units (OTUs) in the environmental samples. Genotypes obtained from Denaturing Gradient Gel Electrophoresis (DGGE) band sequences are marked by solid circles, while genotypes from cultures are indicated by open circles. When a DGGE band class was present in several samples, at least two bands were sequenced. For OTU 16ST44, two different groups can be distinguished because of an 11 nucleotides insertion which is present in several sequences of this cluster.

\begin{tabular}{|c|c|c|c|c|c|c|c|c|c|c|}
\hline \multirow[t]{2}{*}{ OTU* } & \multicolumn{10}{|c|}{ Sample } \\
\hline & UN33 & UN34 & UN42 & UN50 & KD144 & UR160 & UR164 & UR183 & UN195 & UN196 \\
\hline 16ST10 (Phormidium priestleyi) & & & & & & & & & O & \\
\hline 16ST21 (Coleodesmium sp.) & & & & & & & $\bullet$ & $\bullet$ & $\bullet$ & \\
\hline 16ST34 (Nostoc sp.) & & & & & & & & O & & \\
\hline 16ST42 (Cyanothece sp.) & & & & & & $\bullet$ & $\bullet$ & $\bullet$ & & \\
\hline 16ST44a (Phormidium autumnale) & $\bullet$ & $\bullet$ & & $\bullet$ & $\bullet$ & $\bullet$ & & $\bullet$ & $\bullet$ & $\bullet$ \\
\hline 16ST73 (Leptolyngbya sp.) & $\bullet$ & $\bullet$ & & $\bullet$ & • & $\bullet$ & & $\bullet$ & $\bullet$ & \\
\hline 16ST83 (Stigonema sp.) & & & & & & & $\bullet$ & & & \\
\hline 16ST84 (Cyanothece sp.) & & & & & & $\bullet$ & $\bullet$ & $\bullet$ & & \\
\hline 16ST85 (Cyanothece sp.) & & & & & & & $\bullet$ & & & \\
\hline 16ST86 (Leptolyngbya sp.) & & & & & - & & & $\bullet$ & $\bullet$ & \\
\hline 16ST87 (Oscillatoriales) & & & & & & & $\bullet$ & & & \\
\hline 16ST88 (Chroococcus sp.) & & & $\bullet$ & & & & & & & \\
\hline
\end{tabular}

*the names of the species in brackets correspond with the related morphologies as seen in Table $\mathrm{V}$. 


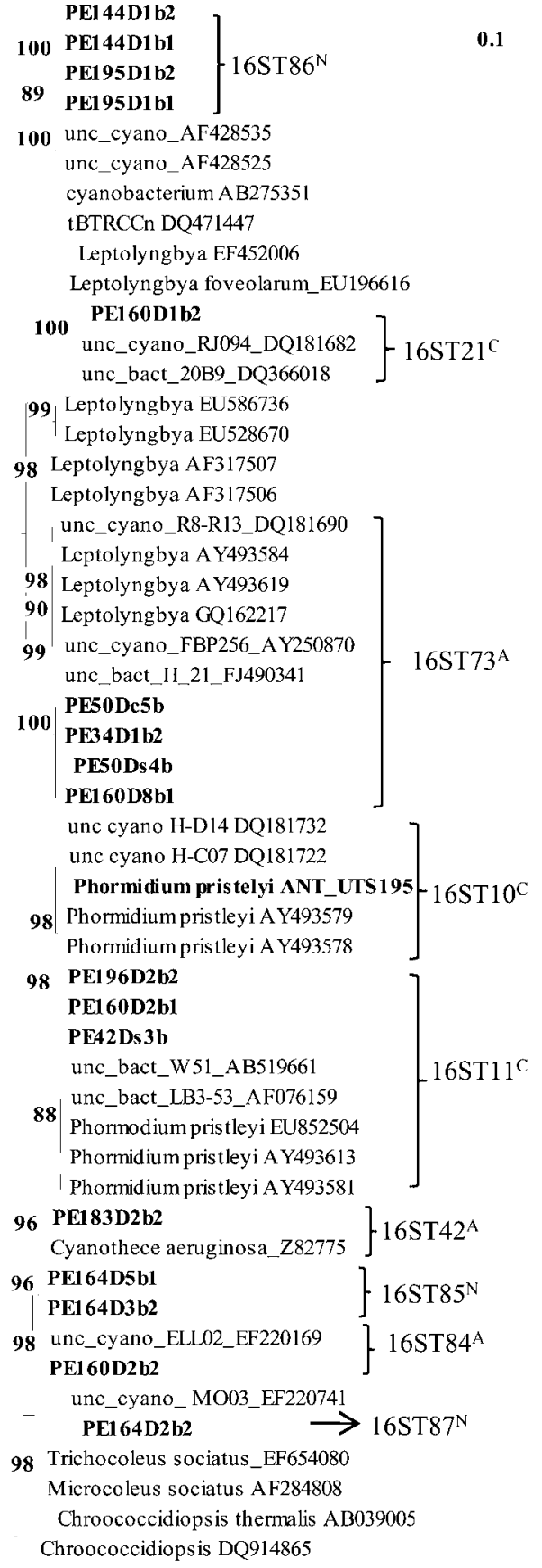

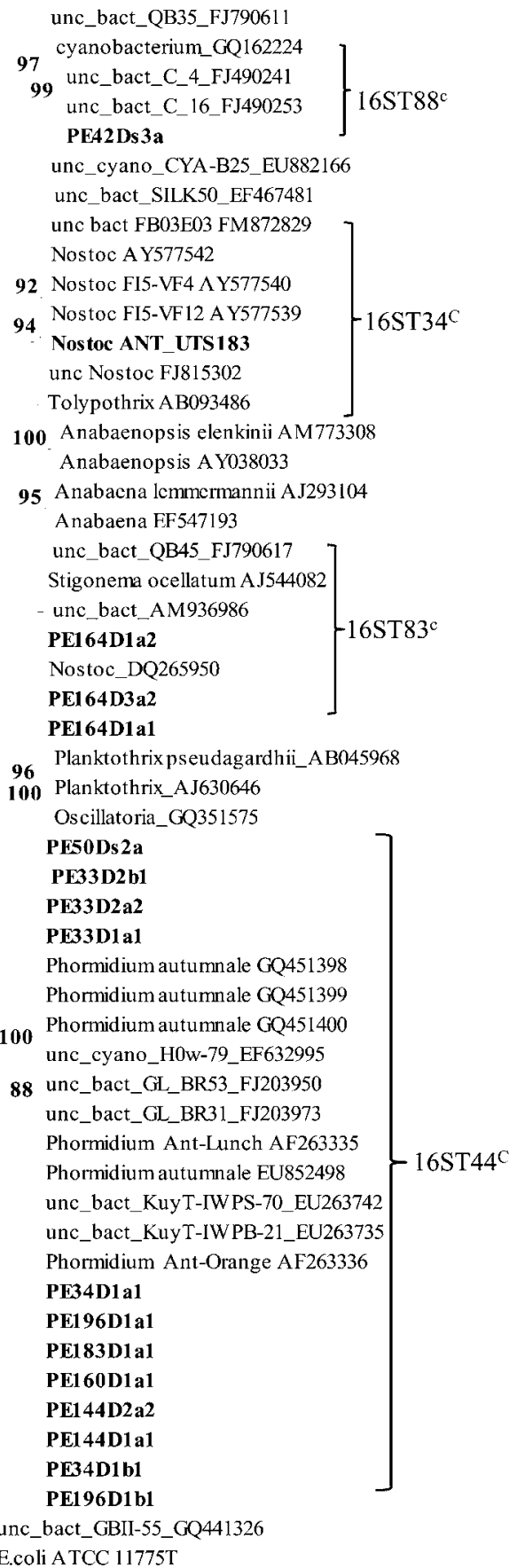

Fig. 3. Distance tree based on partial 16S rRNA gene sequences (Escherichia coli positions 410-780) constructed by neighbour-joining with TREECON (Van de Peer \& De Wachter 1997). The dissimilarity values were corrected for multiple substitutions by the method of Jukes \& Cantor and were used to calculate a distance matrix. A bootstrap analysis was performed that involved construction of 1000 resampled trees (values indicated at the node). Only bootstrap values greater than $85 \%$ are shown at the corresponding node. The tree comprised the sequences from DGGE bands (in bold) and their three most similar strain sequences and two uncultured sequences from RDPII (http://rdp.cme.msu.edu, accessed March 2011). The E. coli sequence (ATCC 11775 T) was used as out-group. The operational taxonomic unit (OTU) numbers are indicated on the right. The scale above indicates the evolutionary distance (0.1 mutation per position). ${ }^{\mathrm{A}}$ potentially Antarctic endemic OTU, ${ }^{\mathrm{C}}$ cosmopolitan OTU, ${ }^{\mathrm{N}}$ never recorded before OTU.

quality to sequence with $16 \mathrm{~S} 378 \mathrm{~F}$ and $16 \mathrm{~S} 781 \mathrm{R}$ primers. 35 sequences were determined in both directions to obtain c. $370 \mathrm{bp}$ (therefore called "representative sequences") and used to construct a distance tree. Sixteen other sequences were determined only in one direction. In summary, 51 partial 16S rRNA gene sequences were obtained in this

\section{CAMBRIDGE JDURNALS}


Table IV. Representative sequences and their related sequences (BLAST analysis on Escherichia coli positions 405-780). Representative sequences have been sequenced in both directions and included in the phylogenetic tree. Placenames in inverted commas are unofficial names.

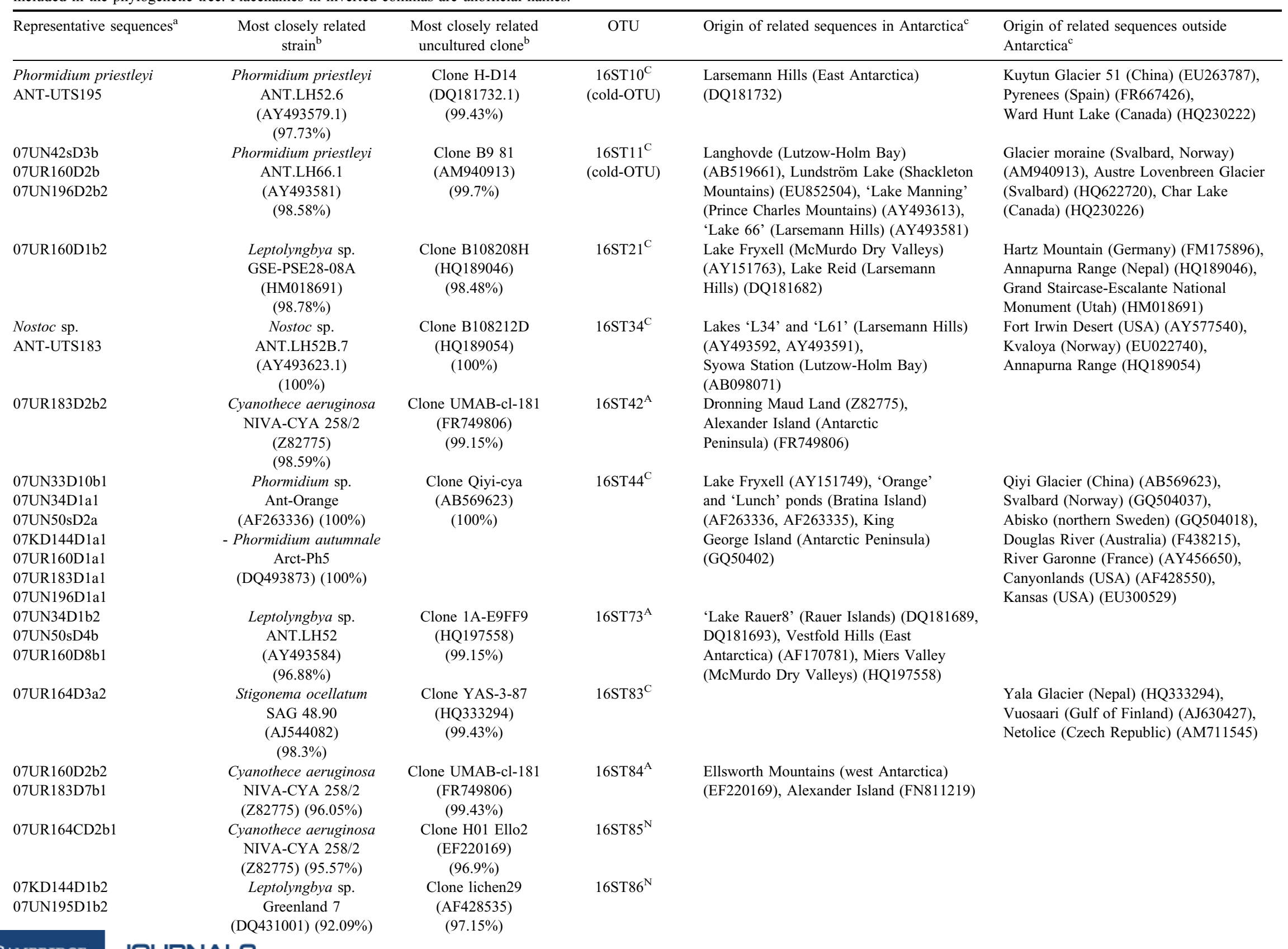




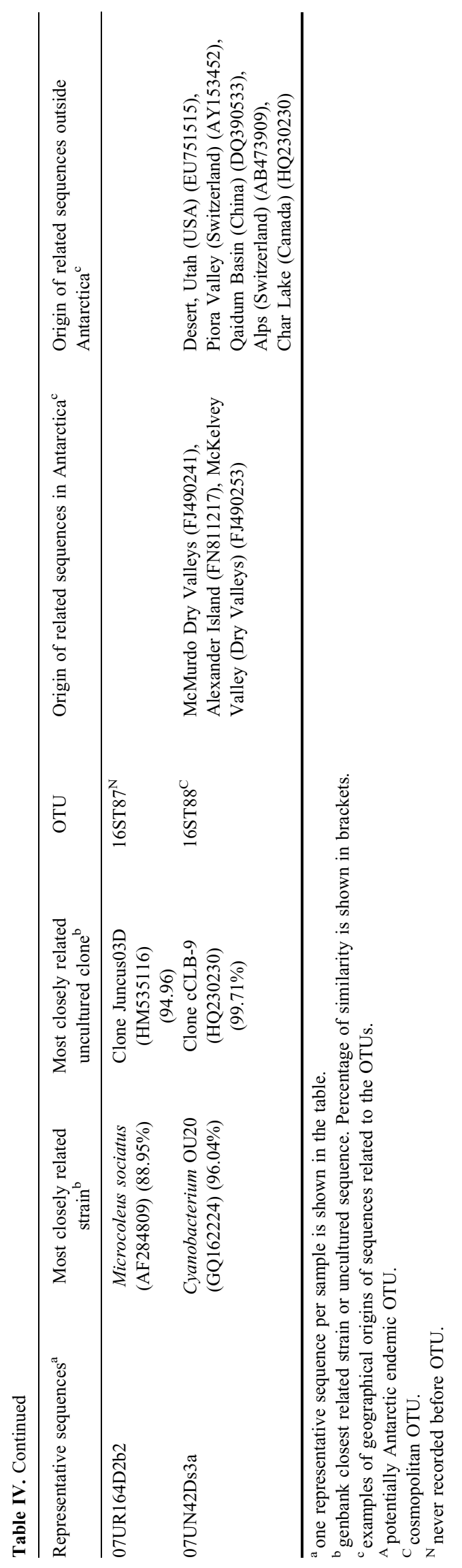

study and deposited into Genbank with the following accession numbers (HM101176-HM101227).

The partial 16S rRNA sequences corresponding to the Escherichia coli (Migula) Castellani and Chalmers positions 405-780 were used for Basic Local Alignment Search Tool (BLAST) analyses (23 March 2011). Chimera detection was performed using the Chimera_Check program in the Ribosomal Database Project (Maidak et al. 2001). A distance tree was constructed with the software package TREECON for Windows 1.3b (Van de Peer \& De Wachter 1997). The dissimilarity values were corrected for multiple substitutions by the model of Jukes \& Cantor (1969) and were used to calculate a distance matrix. The distance tree was constructed by the neighbour-joining method (Saitou \& Nei 1987). Aligned partial 16S rRNA gene sequences corresponding to $E$. coli positions 410-780 were used for most of the sequences. A bootstrap analysis was performed that involved the construction of 1000 resampled trees. When several bands with identical sequences were obtained for one sample, only one representative is shown in the tree. The tree combines the sequences obtained in this study, as well as their three most similar strain sequences and two uncultured sequences retrieved with the option Seqmatch from RDP (http://rdp.cme.msu.edu, accessed March 2011) (Maidak et al. 2001).

The sequences were grouped into operational taxonomic units (OTUs) with the software DOTUR using the average neighbour method (Schloss \& Handelsman 2005). We define the OTUs as groups of sequences that exhibit more than $97.5 \%$ similarity with each other, using the E. coli positions 405-780 (except in some cases where the sequences were slightly shorter) (Taton et al. 2003).

\section{Results}

Microscopy of strains and samples

Ten morphotypes were observed (Fig. 2) in the ten environmental samples (Table II), four belonging to the order Oscillatoriales, two to the Nostocales, three to the Chroococcales, and one to the Stigonematales. From the Oscillatoriales order, Phormidium priestleyi Fritsch (1.9-1.8 $\mu \mathrm{m}$ isodiametric cells) (Fig. 2a) was observed in five samples (Table II). The strain $P$. priestleyi ANTUTS195 was isolated from sample UN195 (Fig. 2b). Cells were quadratic ( $2 \mu \mathrm{m}$ wide, $2.2 \mu \mathrm{m}$ long) in filaments with frequent false branching. Interestingly, the thick sheath was blackish and probably contained scytonemin. Phormidium autumnale (Ag.) Gom. (cells 3-4 $\mu \mathrm{m}$ long, 6-7 $\mu \mathrm{m}$ wide) (Fig. 2c \& d) was detected in seven samples (Table II). Another Phormidium morphotype with smaller cells $(1.8 \mu \mathrm{m}$ wide, $1.4 \mu \mathrm{m}$ long), that was rare in the samples, was observed in two samples (Fig. 2e). In addition, a Leptolynbgya sp., related to the Leptolyngbya antarctica (West \& West) Anagnostidis \& Komárek described by Taton et al. (2006a) (Fig. 2f) was detected in three samples as minor component. 
Table V. Correspondence between the morphological characterization and the molecular detection. Morphotypes (Fig. 1) are indicated by $\mathbf{\Lambda}$, genotypes are indicated by $\bullet$.

\begin{tabular}{|c|c|c|c|c|c|c|c|c|c|c|c|}
\hline \multirow[t]{2}{*}{ Morphotype } & \multirow[t]{2}{*}{ OTUs } & \multicolumn{10}{|c|}{ Sample } \\
\hline & & UN33 & UN34 & UN42 & UN50 & KD144 & UR160 & UR164 & UR183 & UN195 & UN196 \\
\hline Asterocapsa $\mathrm{sp}$. & - & & & & & & & $\Delta$ & & & \\
\hline Cyanothece aeruginosa & 16ST42, 16ST84, 16ST85 & & & $\Delta$ & & $\Delta$ & $\Delta, \bullet$ & $\boldsymbol{\Delta}, \bullet$ & $\Delta, \bullet$ & & \\
\hline Leptolyngbya $\mathrm{sp}$. & $16 \mathrm{ST} 73,16 \mathrm{ST} 86$ & $\bullet$ & $\bullet$ & & $\bullet$ & $\boldsymbol{\Delta}, \bullet$ & $\boldsymbol{\Delta}, \bullet$ & & & $\mathbf{\Delta}, \bullet$ & \\
\hline Oscillatoriales & 16ST87 & & & & & & & $\bullet$ & & & \\
\hline Phormidium priestleyi & 16ST10, 16ST11 & & $\Delta$ & $\Delta, \bullet$ & & & $\bullet$ & $\bullet$ & & $\mathbf{\Delta}^{\mathrm{A}}, \bullet$ & $\Delta, \bullet$ \\
\hline Coleodesmium sp. & 16ST21 & & & & & & $\Delta$ & $\bullet$ & $\Delta, \bullet$ & $\boldsymbol{\Delta}, \bullet$ & \\
\hline Nostoc sp. & $16 \mathrm{ST} 34$ & $\Delta$ & & & & & & & $\mathbf{\Delta}^{\mathrm{A}}, \bullet$ & $\Delta$ & $\boldsymbol{\Delta}$ \\
\hline Stigonema sp. & $16 \mathrm{ST} 83$ & & & & & & & $\Delta, \bullet$ & & & \\
\hline
\end{tabular}

A indicates that the genotype was only detected thanks to an isolated strain.

It showed narrow filaments with thin sheaths, and the cells were $1 \mu \mathrm{m}$ wide, 2-3 times longer than wide.

Regarding the Nostocales, Nostoc sp. was found in four samples (Table II). Colonies were dark green round (70-130 $\mu \mathrm{m}$ diameter). Rounded to quadratic cells were often flattened at the cross-walls $(3-4 \mu \mathrm{m})$. Heterocysts were present, terminally or intercalary in the trichomes, and were two times bigger than the vegetative cells (Fig. 2g). The strain Nostoc ANT-UTS183 was isolated from sample UR183. Cells were irregularly rounded, sometimes flattened at the cross-walls, with variable sizes up to $2 \mu \mathrm{m}$. Yellowbrownish coloured sheaths surrounded single filaments in the early stages although the filaments were also observed without sheaths (Fig. $2 \mathrm{~h} \& \mathrm{i}$ ). Coleodesmium sp. was observed in three samples (Fig. 2j). It showed cells with big basal heterocysts and single filaments enveloped by a thick sheath (up to $3 \mu \mathrm{m}$ ) with cells longer $(7-8 \mu \mathrm{m})$ than wide $(1.6-3.5 \mu \mathrm{m})$.

Within the Chroococcales order, Chroococcus sp. (10-13 $\mu \mathrm{m}$ cell diameter) possessed a thick external sheath $(4 \mu \mathrm{m})$ (Fig. 2k). It was found in six of our samples on the ridge and the western part of the Utsteinen Nunatak (Table II), but it was a minor component. Asterocapsa sp. (Fig. 2l) (3.5 $\mu \mathrm{m}$ wide, $4 \mu \mathrm{m}$ long) appeared in only one sample (UR164). It showed irregular, from spherical to oblong shaped cells. It was present in groups of two cells, without or with a very thin sheath in the early development stages. Moreover, it often appears as colonies (30-50 $\mu \mathrm{m}$ diameter) of several cells enveloped by a thick mucilaginous pigmented sheath (reddish or blackish). Cyanothece aeruginosa (Nägeli) Komárek (Fig. 2m) was quite conspicuous, appearing in five of the studied samples. Cells were solitary (10-18 $\mu \mathrm{m}$ wide, $12-30 \mu \mathrm{m}$ long) or in groups of two after division.

We have only found one morphotype from the Stigonematales order (Stigonema sp.) in sample UR164 (Fig. 2n), where it was dominant. Cells showed a large variability in size $(6-7 \mu \mathrm{m}$ wide, $12-18 \mu \mathrm{m}$ long) and the filaments exhibited a true branching. The sheath was thick
$(2-4 \mu \mathrm{m})$ and brownish. Nevertheless, no heterocysts were observed in the environmental sample.

\section{Efficiency of the DNA extraction methods}

The three samples used for the comparison were selected on the basis of preliminary microscopic observations. We chose two samples containing a weak diversity (one to three morphotypes) and cyanobacteria with thin sheaths (UN42 and UN50), and one sample containing higher diversity (four morphotypes) and cyanobacteria with thick sheaths (UR164).

Both DNA extraction methods (Taton- and Wilson-derived methods) gave similar DGGE patterns with an identical operational taxonomic unit (OTU) richness (number of OTUs per sample) for samples UN42 (OTUs 16ST11 and 16ST88) and UN50 (16ST44 and 16ST73) (Table III \& Fig. S10).

The richest sample, UR164, was used for a second test, in addition to the comparison of DNA extraction efficiencies. The DGGE was performed, either in the 'classical' way (two successive PCR reactions) or a direct PCR was carried out. The DGGE based on direct PCR showed the same OTU diversity for both extraction methods and sequences from the OTUs 16ST83, 16ST84 and 16ST87 were obtained in both cases. However, bacterial sequences were also amplified. In contrast, with the classical method, no bacterial sequences were retrieved, whereas four additional cyanobacterial OTUs were found (16ST11, 16ST21, 16ST42 and 16ST85) (Fig. S11). Therefore, we have used the PCR results obtained with the classical DGGE to analyse the correspondence between morphotypes and genotypes.

\section{Molecular diversity}

All the 35 representative sequences were grouped into 13 OTUs (Fig. 3). The OTUs richness per sample varied between two and seven (Table III). Six out of 13 OTUs appeared to be potentially endemic to Antarctica, including three OTUs (16ST85, 16ST86 and 16ST87) that have never

\section{CAMbridge JDURNALS}


been recorded before, showing a low percentage similarity (94-97\%) with the most related sequences (Table IV).

\section{Discussion}

Role of the DNA extraction methods for the diversity assessment

Classical DNA extraction protocols may not be sufficiently efficient to disrupt the complex polysaccharidic matrix often formed by cyanobacterial mats, especially in terrestrial habitats. The Taton-derived method was originally developed for benthic cyanobacteria in Antarctic lakes (Hodgson et al. 2010). However, terrestrial samples may include morphotypes with thicker polysaccharidic sheaths. Therefore, another extraction method derived from Wilson (1992) was performed. Indeed, several morphotypes are currently underrepresented in the genomic databases, e.g. Asterocapsa and Stigonema, as there is only one sequence of Stigonema (AJ544082) in Genbank and none from Asterocapsa.

The comparison of the two extraction methods used in this study, suggests a lower efficiency of both methods when there were thick polysaccharidic sheaths around the cells. Indeed, in sample UR164, the Asterocapsa and Chroococcus sequences were not detected by any of the two extraction methods (Table V), though the morphotypes were observed by microscopy. This implies that the extraction methods used in environmental studies can produce a bias and underestimate the diversity.

The Wilson-derived method differs mainly from the Taton-derived method by the presence of a CTAB based step. Cetyltrimethylammonium bromide is a cationic detergent that helps to remove exopolysaccharides (Azeredo \& Oliveira 1996) which precipitate under low salinity conditions. Thus, exopolysaccharides removal should increase the DNA recovery. In addition, the Taton-derived method includes the use of lyzozyme but not of proteinase $\mathrm{K}$, whereas the contrary was performed in the Wilson-derived method. In the Wilson-derived method we also added sarkosyl, which could help to remove part of the lipopolysaccharides to improve cell lysis (Wu et al. 2000). A good solution could be the combination of both CTAB and lysozyme. A close monitoring of cell breakage by microscopic observations could also be used to better assess the efficiency of other extraction variants, in the future.

\section{Complementarity of the polyphasic approach}

With this polyphasic approach, in the ten samples (extracted by the Taton-derived method) at least two out of ten morphotypes (Asterocapsa sp. and Nostoc sp.) were never detected by molecular methods from the environmental samples, although a Nostoc sp. sequence was obtained from the isolated strain from sample UR183 (Nostoc ANT-UTS183). In addition, Chroococcus sp. was detected by DGGE only in one out of the six samples where
Chroococcus morphotypes were observed (Table V). Leptolyngbya antarctica was not observed by microscopy in three samples (UN33, UN34 and UN50) where related sequences were obtained by DGGE. This could be due to their low abundance and very thin filaments without sheaths, which made them hard to distinguish in the environmental samples, although their cells can be easily disrupted and their DNA amplified.

The affiliations of the OTUs to the morphotypes were realized considering the closest strain sequences obtained from a BLAST analysis and summarized in Table V. In general, the identification was quite straightforward. For instance, the link between the observed Cyanothece aeruginosa morphotype and the C. aeruginosa genotype is highly reliable for the OTU 16ST42. Indeed, the only strain with high similarity levels (99\%) is C. aeruginosa NIVA-CYA 258/2. The short fragment (c. $400 \mathrm{bp}$ ) obtained by DGGE does not allow for an accurate identification in all cases, though Taton et al. (2003) calculated for 53 strains that the use of complete or partial sequences did not change significantly the similarities obtained during pairwise comparisons. Indeed, the average similarities were between 97.05 and $97.01 \%$ for complete and partial (E. coli positions 405-780) 16S rRNA sequences, respectively, with a standard deviation of 1.24. The OTU 16ST83, detected in the sample UR164 is closely related to a Stigonema sp. sequence (AJ544082) (98\%) but also to Nostoc sp. (GU062469, AM711545 and others) (97.5\%) and Anabaena sp. (EF568906, EF568904) (98\%) sequences. Since Stigonema is dominant in the sample, we relate this morphotype to OTU 16ST83. Inclusion of the sequences of OTU 16ST73 and 16ST86 in a database containing c. 3000 cyanobacterial sequences (data not shown), clearly situates both OTUs into a Leptolyngbya sp. cluster. Finally, the sequences of the OTU 16ST87 are similar (95\%) to those of uncultured cyanobacteria from wetland sediments, but the first strain sequence (Microcoleus) is only $88.95 \%$ similar.

In this work, we usually found band patterns containing several bands in the same lane for a single genotype. This was already observed for planktonic cyanobacteria (Boutte et al. 2006) and can be due to the presence of multiple melting domains in a rather large amplicon. Several bands derived from a single species can be caused by microvariation divergences (Kisand \& Wikner 2003). These can come from natural variability or artificial introduction due to polymerase mistakes during PCR (Speksnijder et al. 2001). It has been also previously reported that dominant amplicons may produce several bands that are dispersed in the gel (Nikolausz et al. 2005).

This study supports the complementarity of both analyses which was advocated by Taton et al. (2006b) and Komárek et al. (2008).

\section{Molecular richness and geographical distribution}

We have observed a high proportion of potentially endemic OTUs ( 6 out of 13), including three OTUs which have been

\section{CAMBRIDGE JDUNALS}


recorded here for the first time. In addition, two OTUs (16ST10, 16ST11) have been described only in cold habitats (Table IV). At the local scale, six OTUs were unique for a single sample. In contrast, five OTUs were recorded both in the Utsteinen Nunatak and in the ridge including the three OTUs found in the sample KD144, from the distant Ketelersbreen dry valley $(c .20 \mathrm{~km}$ distant and c. $330 \mathrm{~m}$ higher in altitude) (Table III). These data suggest an extensive spreading of the cyanobacterial flora in this area. This could be an indication of an effective propagation in this region, maybe due to the influence of winds and air transported particles.

Cyanobacterial richness in Antarctic coastal lakes has been studied by Taton et al. (2006a) and ranged between 4 and 12 OTUs per lake. Thus, a single coastal lake can gather as much diversity as our entire sample collection from the Sør Rondane Mountains. However, terrestrial microorganisms must survive the fluctuating temperatures and high UV radiations at the surface. In contrast, lakes can provide protection against these factors as water buffers the extreme temperatures and the surface ice layer acts as a filter for UV (Kepner et al. 2000). Therefore, a larger diversity is expected in lakes than on soils and rocks.

Several authors have studied Antarctic terrestrial habitats to estimate the cyanobacterial diversity by morphological or molecular methods, but studies combining both approaches are still missing. For instance, only the morphological diversity was studied in the four following papers. Komárek et al. (2008) studied several locations on James Ross Island (Antarctic Peninsula), comprising terrestrial and aquatic environments, and described 44 distinct morphotypes. Two surveys were carried out in polygon soil locations in the Antarctic Peninsula. The first was done by Davey \& Rothery (1993) who observed six morphospecies in 65 soils samples at Signy Island and the second was realized by Mataloni et al. (2000) who detected 15 morphospecies in 18 soil samples at Cierva Point. Büdel et al. (2008) described three cyanobacterial morphospecies in chasmoendolithic samples of granite rocks in the Taylor Valley (McMurdo Dry Valleys). In contrast, other terrestrial biotopes were investigated only by molecular techniques. For example, Brinkmann et al. (2007) observed 14 genotypes in 27 soil samples from three polygons of the more temperate Coal Nunatak (Alexander Island, Antarctic Peninsula). However, the sequences were not deposited in Genbank, and thus cannot be analysed for the presence of plastids. Smith et al. (2006) found eight groups of cyanobacterial sequences (similarity levels of $95-99 \%$ to Genbank sequences) in three mineral soil samples from the McMurdo Dry Valleys.

Previous studies postulated a direct relationship between latitude and diversity for bacteria and other Antarctic flora and fauna, although other parameters could play important roles (Yergeau et al. 2007 and references therein). Coastal areas of Antarctica seem to possess higher cyanobacterial diversity than higher latitude continental regions, although some particular locations can host an elevated diversity, acting as hotspots or refugia. For a synthesis, Namsaraev et al. (2010) calculated the number of cyanobacterial OTUs found in all studied terrestrial Antarctic habitats, including this dataset. The number of OTUs ranged from one (e.g. South Orkney Islands) to nine (Alexander Island). The analysis of a latitudinal gradient from $60-82^{\circ} \mathrm{S}$ suggested an increased number of OTUs between $70^{\circ} \mathrm{S}$ and $80^{\circ} \mathrm{S}$, that could be explained by the disappearance of the vegetation cover which can compete with cyanobacteria for resources. Interestingly, the diversity found in the Sør Rondane Mountains area is higher than other locations at similar latitudes such as the Mars Oasis (five samples containing eight OTUs) or the Luther Valley (two OTUs), which seems to be in concordance with the possible role of this area as biological refuge. Further south of $80^{\circ} \mathrm{S}$, the cyanobacterial richness decreased again, probably due to the very harsh environmental conditions.

\section{Conclusions}

Morphological and molecular characterizations of the cyanobacterial diversity in ten Antarctic terrestrial samples within the Sør Rondane Mountains area were performed in this work. Two DNA extractions methods were tested for three samples.

i) DNA extraction remains a problem, impeding a highresolution image of the diversity contained in environmental samples. Each sample should be preliminarily studied by microscopy to decide which extraction method should be adopted. Future efforts should be made to develop effective methods for the ensheathed taxa with additional steps allowing the destruction of the exopolysaccharidic matrix.

ii) The persistence of nunataks in Dronning Maud Land from at least $39.4 \mathrm{ka} \mathrm{BP}$ together with the relatively high cyanobacterial diversity found in comparison to other regions, and the presence of three OTUs never recorded before, could indicate that this area acted as a biological refuge during the succession of glaciations following the formation of the first ice sheets on Antarctica. However, additional studies are needed to extend the range of sampling sites in the area and the range of organisms studied, as well as geomorphological determinations of the maximum ice thicknesses in the region during past glaciations and cosmogenic isotope age determinations of the oldest exposed rocks.

iii) The cyanobacterial diversity found in these ten samples shows a rather high degree of endemism. Locally, the same OTUs can be found in several samples and thus seem to easily spread. Therefore, special precautions should be taken to avoid the introduction of non-indigenous species through the anthropogenic activities in and around the new Princess Elizabeth Station. Moreover, this baseline data could be compared with future analyses to indicate if the precaution measures taken under the Belgian environmental, health and safety guidelines cited in the Comprehensive Environmental

\section{CAMBRIDGE JDURNALS}


Evaluation (BelSPO 2007) and the Madrid protocol guidelines, were effective or not to control the introduction of non-indigenous species.

\section{Acknowledgements}

This paper forms a contribution to the Belgian Research Programme on the Antarctic (Belgian Federal Science Policy Office (BelSPO)), Project no. SD/BA/853 (ANTAR-IMPACT, www.antar-impact.ulg.ac.be). The BELARE 2007 expedition was also funded by BelSPO. Thanks are due to the IPF for the organization of the expedition. The authors are indebted to A. Hubert, N. Johnson, and J. Berte for their valuable assistance with field samplings. We would like to thank the Foundation "Alfonso Martin Escudero" for the funding of Rafael Fernandez-Carazo. Annick Wilmotte is Research Associate of the FRS-FNRS and benefited from the Credit FNRS 1.5.104.04. Thanks are due to Dominic Hodgson (British Antarctic Survey) and an anonymous reviewer for their critical revision of this manuscript. This paper also contributes to the SCAR Evolution and Biodiversity in Antarctica (EBA) research programme, and the MERGE IPY project.

\section{Supplemental material}

Pictures and maps from the Sør Rondane area and DGGE band patterns and analysis of the DGGE band patterns will be found at http://dx.doi.org/10.1017/S0954102011000824.

\section{References}

Azeredo, J. \& Oliveira, R. 1996. A new method for precipitating bacterial exopolysaccharides. Biotechnology Techniques, 10, 341-344.

Belspo (Belgian Federal Science Policy Office). 2007. Construction and operation of the new Belgian research station, Dronning Maud Land, Antarctica. Final Comprehensive Environmental Evaluation (CEE). 123 pp. www.belspo.be/belspo/BePoles/doc/final_CEE_en.pdf.

Boutte, C., Grubisic, S., Balthasart, P. \& Wilmotte, A. 2006. Testing of primers for the study of cyanobacterial molecular diversity by DGGE. Journal of Microbiological Methods, 65, 542-550.

Brinkmann, M., Pearce, D.A., Convey, P. \& Ott, S. 2007. The cyanobacterial community of polygon soils at an inland Antarctic nunatak. Polar Biology, 30, 1505-1511.

Büdel, B., Bendix, J., Bicker, F.R. \& Green, T.G.A. 2008. Dewfall as a water source frequently activates the endolithic cyanobacterial communities in the granites of Taylor Valley, Antarctica. Journal of Phycology, 44, 1415-1424.

Convey, P., Gibson, J.A.E., Hillenbrand, C.D., Hodgson, D.A., Pugh, P.J.A., Smellie, J.L. \& Stevens, M.I. 2008. Antarctic terrestrial life - challenging the history of the frozen continent? Biological Reviews, 83, 103-117.

DAVEy, M.C. \& Rothery, P. 1993. Primary colonization by microalgae in relation to spatial variation in edaphic factors on Antarctic fellfield soils. Journal of Ecology, 81, 335-343.

Frenot, Y., Chown, S.L., Whinam, J., SelkiRK, P.M., Convey, P., Skotnicki, M. \& Bergstrom, D.M. 2005. Biological invasions in the Antarctic: extent, impacts and implications. Biological Reviews, 80, 45-72.

Gordon, D.A., Priscu, J. \& Giovannoni, S. 2000. Origin and phylogeny of microbes living in permanent Antarctic lake ice. Microbial Ecology, 39, 197-202.
Jukes, T.H. \& Cantor, C.R. 1969. Evolution of protein molecules. In MunRo, H.N., ed. Mammalian protein metabolism. New York: Academic Press, 21-132.

Hodgson, D.A., Convey, P., Verleyen, E., Vyverman, W., McInnes, S.J., Sands, C.J., Fernández-Carazo, R., Wilmotte, A., De Wever, A., Peeters, K., Tavernier, I. \& Willems, A. 2010. The limnology and biology of the Dufek Massif, Transantarctic Mountains $82^{\circ}$ South. Polar Science, 4, 197-214.

Kepner, R.L., Wharton, R.A., Collier, R.D., Cockell, C.S. \& Jeffrey, W.H. 2000. UV radiation and potential biological effects beneath the perennial ice cover of an Antarctic lake. Hydrobiologia, 427, 155-165.

KisAND, V. \& WiKNER, J. 2003. Limited resolution of 16S rDNA DGGE caused by melting properties and closely related DNA sequences. Journal of Microbiological Methods, 54, 183-191.

KomÁreK, J. \& ANAgnostidis, K. 2005. Cyanoprokaryota. 2. Oscillatoriales. In Büdel, B., Krienitz, L., Gärtner, G., Schagerl, M., eds. Süsswasserflora von Mitteleuropa, Bd 19/2. Heidelberg: Springer, 759 pp.

KomÁrek, J., Elster, J. \& Komárek, O. 2008. Diversity of the cyanobacterial microflora of the northern part of James Ross Island, NW Weddell Sea, Antarctica. Polar Biology, 31, 853-865.

Lawver, L.A. \& Gahagan, L.M. 2003. Evolution of Cenozoic seaways in the circum-Antarctic region. Palaeogeography, Palaeoclimatology, Palaeoecology, 198, 11-37.

Maidak, B.L., Cole, J.R., Lilburn, T.G., Parker JR, C.T., Saxman, P.R., Farris, R.J., Garrity, G.M., Olsen, G.J., Schmidt, T.M. \& Tiedje, J.M. 2001. The RDP-II (Ribosomal Database Project). Nucleic Acids Research, 29, 173-174.

Marshall, D.J. \& Coetzee, L. 2000. Historical biogeography and ecology of a continental Antarctic mite genus, Maudheimia (Acari, Oribatida): evidence for a Gondwanan origin and Pliocene-Pleistocene speciation. Zoological Journal of the Linnean Society, 129, 111-128.

Mataloni, G., Tell, G. \& Wynn-Williams, D.D. 2000. Structure and diversity of soil algal communities from Cierva Point (Antarctic Peninsula). Polar Biology, 23, 205-211.

Namsaraev, Z., Mano, M.J., Fernandez, R. \& Wilmotte, A. 2010. Biogeography of terrestrial cyanobacteria from Antarctic ice-free areas. Annals of Glaciology, 51, 171-177.

Nikolausz, M., Sipos, R., Revesz, S., Szekely, A. \& Marialigeti, K. 2005. Observation of bias associated with re-amplification of DNA isolated from denaturing gradient gels. FEMS Microbiology Letters, 244, 385-390.

Nübel, U., Garcia-Pichel, F. \& Muyzer, G. 1997. PCR primers to amplify $16 \mathrm{~S}$ rRNA genes from cyanobacteria. Applied and Environmental Microbiology, 63, 3327-3332.

Pattyn, F., Matsuoka, K. \& Berte, J. 2000. Glacio-meteorological conditions in the vicinity of the Belgian Princess Elisabeth Station, Antarctica. Antarctic Science, 22, 79-85.

Rippka, R.J., Waterbury, J.B. \& Stanier, R.Y. 1981. Isolation and purification of cyanobacteria: some general principles. In STARR, M.P., Stolp, H., Trüper, H.G., Balows, A. \& Schlegel, H.G., eds. The prokaryotes, vol. 1. Berlin: Springer, 212-220.

SAitou, N. \& NeI, M. 1987. The neighbor-joining method: a new method for reconstructing phylogenetic trees. Molecular Biology and Evolution, 4, 406-425.

Schloss, P.D. \& Handelsman, J. 2005. Introducing DOTUR, a computer program for defining operational taxonomic units and estimating speciesrichness. Applied and Environmental Microbiology, 71, 1501-1506.

Smith, J.J., Tow, L.A., Stafford, W., Cary, C. \& Cowan, D.A. 2006. Bacterial diversity in three different Antarctic cold desert mineral soils. Microbial Ecology, 51, 413-421.

Speksnijder, A., KowalchuK, G.A., De Jong, S., Kuine, E., Stephen, J.R. \& LAANBROEK, H.J. 2001. Microvariation artifacts introduced by PCR and cloning of closely related $16 \mathrm{~S}$ rRNA gene sequences. Applied and Environmental Microbiology, 67, 469-472. 
Taton, A., Grubisic, S., Brambilla, E., De Wit, R. \& Wilmotte, A. 2003. Cyanobacterial diversity in natural and artificial microbial mats of Lake Fryxell (McMurdo Dry Valleys, Antarctica): a morphological and molecular approach. Applied and Environmental Microbiology, 69, 5157-5169.

Taton, A., Grubisic, S., Balthasart, P., Hodgson, D.A., Laybourn-Parry, J. \& WilmotтE, A. 2006a. Biogeographical distribution and ecological ranges of benthic cyanobacteria in East Antarctic lakes. FEMS Microbiology Ecology, 57, 272-289.

Taton, A., Grubisic, S., Ertz, D., Hodgson, D.A., Piccardi, R., Biondi, N., Tredici, M.R., Mainini, M., Losi, D., Marinelli, F. \& Wilmotte, A. 2006b. Polyphasic study of Antarctic cyanobacterial strains. Journal of Phycology, 42, 1257-1270.

Tin, T., Fleming, Z.L., Hughes, K.A., Ainley, D.G., Convey, P., Moreno, C.A., Pfeiffer, S., Scott, J. \& Snape, I. 2009. Impacts of local human activities on the Antarctic environment. Antarctic Science, 21, $3-33$.

Tripati, A., Backman, J., Elderfield, H. \& Ferretti, P. 2005. Eocene bipolar glaciation associated with global carbon cycle changes. Nature, 436, 341-346.
Van de Peer, Y. \& De Wachter, R. 1997. Construction of evolutionary distance trees with TREECON for Windows: accounting for variation in nucleotide substitution rate among sites. Computer Applications in the Biosciences, 13, 227-230.

VINCENT, W.F. 2000. Evolutionary origins of Antarctic microbiota: invasion, selection and endemism. Antarctic Science, 12, 374-385.

Yergeau, E., Newsham, K.K., Pearce, D.A. \& Kowalchuk, G.A. 2007. Patterns of bacterial diversity across a range of Antarctic terrestrial habitats. Environmental Microbiology, 9, 2670-2682.

WAND, U. \& HeRmichen, W.D. 2005. Late Quaternary ice level changes in central Dronning Maud Land, East Antarctica, as inferred from ${ }^{14} \mathrm{C}$ ages of mumiyo deposits in snow petrel colonies. Geologisches Jahrbuch, B97, 237-254.

Wilson, K. 1992. Preparation of genomic DNA from bacteria. In Ausubel, F.M., Brent, R., Kingston, R.E., Moore, D.D., Seidman, J.G., Smith, J.A., Struhl, K., eds. Current protocols in molecular biology. New York: John Wiley \& Sons, 2-10-2-12.

Wu, X., Zarka, A. \& Boussiba, S. 2000. A simplified protocol for preparing DNA from filamentous cyanobacteria. Plant Molecular Biology Reporter, 18, 385-392.

\section{CAMBrIDGE JDURALS}

